\title{
Mario Eusebi, Les «Lettres à Lucilius» de Sénèque dans un imprimé d'Antoine Vérard
}

\section{Maria Colombo Timelli}

\section{(2) OpenEdition}

1 Journals

\section{Édition électronique}

URL : https://journals.openedition.org/studifrancesi/39052

DOI : 10.4000/studifrancesi.39052

ISSN : 2421-5856

Éditeur

Rosenberg \& Sellier

\section{Édition imprimée}

Date de publication : 1 décembre 2004

Pagination : 343-344

ISSN : 0039-2944

\section{Référence électronique}

Maria Colombo Timelli, « Mario Eusebi, Les «Lettres à Lucilius» de Sénèque dans un imprimé d'Antoine Vérard », Studi Francesi [En ligne], 143 (XLVIII | II) | 2004, mis en ligne le 30 novembre 2015, consulté le 19 mai 2021. URL : http://journals.openedition.org/studifrancesi/39052 ; DOI : https://doi.org/ 10.4000/studifrancesi.39052

Ce document a été généré automatiquement le 19 mai 2021.

\section{(c)}

Studi Francesi è distribuita con Licenza Creative Commons Attribuzione - Non commerciale - Non opere derivate 4.0 Internazionale. 


\title{
Mario Eusebi, Les «Lettres à Lucilius» de Sénèque dans un imprimé d'Antoine Vérard
}

\author{
Maria Colombo Timelli
}

\section{RÉFÉRENCE}

MARIO EUSEBI, Les «Lettres à Lucilius» de Sénèque dans un imprimé d'Antoine Vérard, in Traduction dérimation compilation - La Phraséologie, Actes du Colloque intemational Université McGill, Montréal, 2-3-4 octobre 2000, publiés par Giuseppe Di Stefano et Rose M. Bidler, pp. 249-261 («Le moyen français» 51-52-53, 2002-2003).

1 Les Cuvres de Senecque translatez de latin en françoys par maistre Laurens de Premierfait, publiées à Paris pour Antoine Vérard entre 1500 et 1503, contiennent entre autres les quinze premières lettres à Lucilius. M.E. compare ici deux lettres selon la version transmise par le ms.Bruxelles B.R. 10546 et selon le texte imprimé. Au-delà de l'attribution de la traduction à Laurent de Premierfait, qui ne pourra être éventuellement reconnue que par l'examen complet du corpus, force est de constater l'indépendance de la traduction imprimée à l'égard du texte manuscrit. 